\title{
Determinant of Corporate Cash Holding: Evidence From LQ45 Index Companies on Indonesia Stock Exchange
}

\author{
Ainul Ridha ${ }^{1}$, Dewi Maya Sari ${ }^{2 *}$, Intan Novia Astuti ${ }^{3}$, Dara Angreka Soufyan ${ }^{4}$ \\ \{*dewi@politeknikaceh.ac.id\} \\ ${ }^{1}$ Accounting Department, Sekolah Tinggi Ilmu Ekonomi Sabang, Banda Aceh, Indonesia \\ ${ }^{2}$ Public Sector Accounting Department, Politeknik Aceh, Banda Aceh, Indonesia \\ ${ }^{3}$ Accounting Department, Sekolah Tinggi Ilmu Ekonomi Sabang, Banda Aceh, Indonesia \\ ${ }^{4}$ Accounting Department, Universitas Teuku Umar, Meulaboh, Indonesia
}

\begin{abstract}
This study aims to examine the effect of institutional ownership, profitability and firm size on the cash holding of the LQ45 Index Companies on the Indonesia Stock Exchange. The population of this study is the company of LQ 45 Index on the IDX for the period 2015-2017. A total of 210 companies were determined target populations based on certain criteria. This study uses a regression method for panel data, namely by looking at random effects based on the Hausman test results. The results show that institutional ownership, profitability and firm size have a positive effect on cash holding. The findings are useful for managers, shareholders, investors, regulators and researchers in developing suitable policies
\end{abstract}

Keyword : Study, Profitability, Institutional Ownership.

\section{Introduction}

Indonesia is a country that is still very dependent on the flow of funds from foreign investo rs to automatically stop investment funds from foreign investors when the global financial cris is hit in 2008. As a result, many companies are experiencing a liquidity crisis. To avoid this, it is very important for companies to determine the optimal cash holding level that must be owned by the company Throughout $\backslash$ The development Of a strategy,

holding company cash is an significant financial management consideration, which is not only related to operations and business enhancement but also related to corporate governance and institutional climate [1]. Another view is expressed by [2] that holding cash from companies can reduce the possibility of financial pressure due to unexpected losses. Cash holding is one of the most important policies, but it is very complicated to deal with the company's financial strategy. Cash holding is used as a bridge between retained earnings and investment requirements [3]. Managers as part of companies prefer to maintain cash holding for their own interests rather than increasing payments to shareholders when the company has a bad investment opportunity. Profitability is also expected to affect cash holding. If it is associated with the Pecking Order Theory, an increase in profitability will cause the cash holding to increase because the company will use its profitability to increase liquidity. therefore, companies tend to have more cash holding [4]. Firm size is also estimated to affect cash holding. Large companies have access to good capital markets at lower costs compared to 
small companies that face limitations in funding [5]. Larger companies are assumed to be more successful so they must be able to collect more money, after controlling investment spending [6].

\section{Methodology}

This paper will use EVIEWS version 10. To test panel data there are two regression models used known as the common effect model and the fixed effect model. The Chow test is carried out to select the most suitable model between common effects and fixed effects. Furthermore,

The Hausman test is used to select the mostappropriate model between the model with fixed effect

and the model with random effect. The procedure for the two tests is as follows:

a. Chow Test, $\mathrm{H}_{0}$ the models follow common effect. $\mathrm{H}_{1}$ : model follow fixed effect. Decision: Decline $\mathrm{H}_{0}$ if value of Probability $<\alpha$. Conclusion: If $\mathrm{H}_{0}$ rejected then, fixed effect models better than common effect models.

b. Hausman Test, $\mathrm{H}_{0}$ : models follow random effect. $\mathrm{H}_{1}$ : models follow fixed effect. Decision: Decline $\mathrm{H}_{0}$ if value of Probability $<\alpha$. Conclusion: If $\mathrm{H}_{0}$ rejected then fixed effect models better than random effect models.

The panel data regression equation model in this study can be described as follows:

$C H_{i t}=\alpha+\beta_{1} K I_{i t}+\beta_{2} R O A_{i t}+\beta_{3} S I Z E_{i t}+e_{i t}$

Information:

$$
\begin{array}{ll}
C H_{i t} & =\text { The indicator used to measure cash holding } \\
\alpha & =\text { Constanta } \\
\beta_{1}, \beta_{2,}, \beta_{3}, & =\text { Regression coefficient } \\
K I_{i t} & =\text { The indicator used to measure institutional ownership of } \mathrm{i} \text { company for } \\
\text { year } \mathrm{t} & \\
R O A_{i t} & =\text { The indicator used to measure profitability of } \mathrm{i} \text { company for year } \mathrm{t} \\
S I Z E_{i t} & =\text { The indicator used to measure firm size of } \mathrm{i} \text { company for year } \mathrm{t} \\
\mathrm{e}_{\mathrm{it}} & =\text { epsilon (error term) }
\end{array}
$$

In this study testing hypotheses used include testing regression coefficients together and partial regression coefficients. The research hypothesis will be accepted if $\beta \mathrm{i}(\mathrm{i}=1,2,3)=0$ : $\mathrm{HO}_{1}$ accepted $\left(\mathrm{Ha}_{1}\right.$ decline). If there is at least one $\beta \mathrm{i}(\mathrm{i}=1,2,3) \neq 0: \mathrm{H}_{1}$ decline $\left(\mathrm{Ha}_{1}\right.$ accepted). $\mathrm{H}_{1}$ not decline ( $\mathrm{Ha}_{1}$ dicline) meaning that the independent variables together do not affect the dependent variable, whereas $\mathrm{HO}_{1}$ dicline (Ha accepted) means that the independent variables jointly influence the dependent variable. This research located at IDX with an analysis unit of companies LQ45 Index from 2015 to 2017. The study's timePeriod Is a blend of crossectional, longitudinal (time series) studies.

The data used is data from the tables. The data source used is secondary data in the form of the 2015-2017 financial statements. Data collection techniques used are documentation techniques. The mind map of the research question can be seen visually in Figures 1 . 


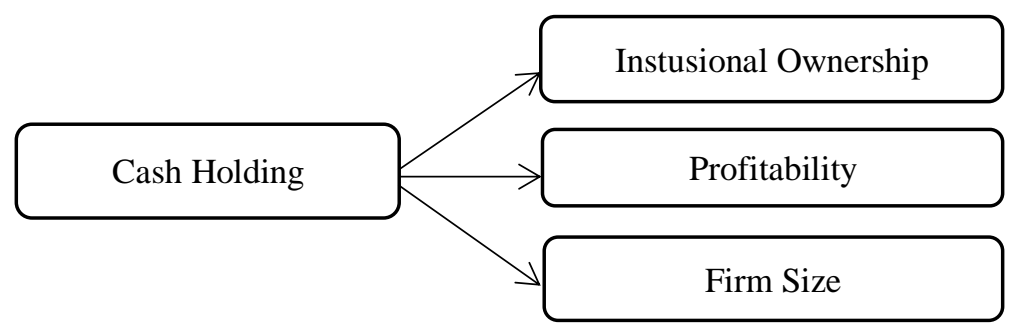

Fig.1. Mind Map Research Question

\section{Result and Discussion}

The results of hypothesis testing are the answers to the hypothesis in this study. The panel data regression results of the effect of institutional ownership, profitability and firm size on corporarate cash holding can be seen in Table 3.

Table 3. Results of Regression

\begin{tabular}{lllll}
\hline Variabel & Coeficient & Std. Error & t-statistic & Prob. \\
\hline Constanta & $-1,442425$ & 0,81377 & $-1,773378$ & 0,0779 \\
Institusional Ownership & 0,022726 & 0,061098 & 0,371960 & 0,7104 \\
Profitability & 0,150914 & 0,123653 & 1,220467 & 0,2240 \\
Firm Size & 0,114202 & 0,059446 & 1,921092 & 0,0564 \\
R-squared & 0,602906 & Durbin-Watson Statistic & 2,606633 \\
Adjusted R-Square & 0,517485 & & & \\
R-squared & & & & \\
F-statistic & 7,058024 & & & \\
Prob (F-statistic) & 0,00000 & & & \\
\hline
\end{tabular}

Based on Table 3 it is known that the constant value is -1.442425 . This constant value indicates that if institutional ownership, profitability and size of the company are considered constant, then the amount of cash holding held by the company will decrease by $14.42 \%$.

\subsection{Selection of the Model Analysis Approach}

Because the analytical method employed in this study is data regression panel which can be made based on three approaches namely the fixed coefficient between time models (common effect model), fixed effect models (random effect models), and random effect models, then to determine which model to use in panel data analysis is based on two tests, namely the chow test and the hausman test.

Table 4. Result of Chow Test

\begin{tabular}{ccll}
\hline Effects Test & Statistic & df & Probability \\
\hline Cross-section F & 6,370880 & $(34,172)$ & 0,000 \\
Cross-section Chi-Square & 171,167131 & 34 & 0,000 \\
\hline
\end{tabular}


Basics on Table 4, it is known that the probability value for cross-section $F$ is 0,000 . This value indicates that the probability value is smaller than the value of $\alpha(0,05)$ so that the decision taken is to reject $\mathrm{H} 0$, meaning that the fixed effect model is better than the common effect model. Because a suitable model is a fixed effect, it is necessary to conduct a Hausman test to see the feasibility of the model between fixed effects or random effects. The Hausman test results can be seen in Table 5 .

Table 5. Result of Hausman Test

\begin{tabular}{cccc}
\hline Effects Test & Chi. Sq. Statistic & Chi-sq.d.f & $\begin{array}{c}\text { Probab } \\
\text { ility }\end{array}$ \\
\hline $\begin{array}{c}\text { Cross-Section } \\
\text { Random }\end{array}$ & 6,61334 & 3 & 0,0853 \\
\hline
\end{tabular}

Basics on Table 5, it is known that the probability value for the random cross-section is 0,0853 . This value indicates that the probability value is greater than the value of $\alpha(0,05)$ so that the decision taken is to accept $\mathrm{H}_{0}$, meaning that the random effect model is better than the fixed effect model. Because the hausman test results choose the random effecti model, then the Lagrangian Multiplier test is needed to determine the best estimate of the model to be used whether or not to use the random effect model.

Table 6. Result of Lagrangian Multiplier Test

\begin{tabular}{lll}
\hline Test & Both & Probability \\
\hline Breusch-Pagan & 105,0870 & 0,0000 \\
\hline
\end{tabular}

Basics on Table 6 above it is known that the Breussch-Pagan Probability value is 0,0000 . These results indicate that if Breusch-Pagan Probability is $0,000<0,05, \mathrm{H} 0$ is rejected, meaning that the model that fits in this study is the Random Effect Model.I

\subsection{Result of Simultaneous Hypothesis Testing}

Basics on Table 3, it is known that the regression coefficient value of the influence of each independent variable on the dependent variable is $0,022726,0.150914$ and 0,114202 , respectively. This regression coefficient indicates that the regression coefficients of institutional ownership, profitability and firm size for cash holding are not equal to zero $(\beta \mathrm{i} \neq 0, \mathrm{i}=1,2,3)$, so Hal is accepted which means institutional ownership, profitability and company size together -sama affects the cash holding company indexed by LQ45 on the Indonesia Stock Exchange.

\subsection{Results of Partial Hypothesis Testing}

\subsubsection{Effect of Institutional Ownership on Corporate Cash Holding}

The value of regression coefficient effect of institutional ownership on cash holding is 0,022726 . This value indicates that $\beta 1 \neq 0$ so that Ha2 is accepted and shows that institutional control has a positive effect on corporate cash holding. This result is in line with the results of the study [7] which shows that institutional control has a positive effect on cash holding. When there is an increase in institutional ownership, there will be more company external part that also as owners of the company will oversee the survival of the company and all its activities. The share owner by the institution is referred to as the principal or facilitator who supports the company through the funds provided. The funds are used not only for company activities, but also as salaries and various other forms of compensation given to management 
in this matter as agents who act as drivers and manage of the company.

\subsubsection{Effect of Profitability on Corporate Cash Holding}

Value of regression coefficient of the effect of profitability on cash holding is 0,150914 . This value indicates that $\beta 2 \neq 0$ so $\mathrm{Ha} 3$ is accepted and shows that profitability has a positive effect on the company's cash holding. Every increase in profitability by $1 \%$ will increase the cash holding by $0,150914 \%$. The results of this study are in line with the results of the study [8], [1], [9], and [10]

Which states that profitability positively affects the holding of cash. High profitability sho ws the ability of the company to generate high profits for the enterprise. Profits would be retai ned profits that are used by businesses as a hedge that will add cash holding. It is in line with $t$ he pecking order principle, which notes that businesses tend to use retained earnings as compl ementary resources.

\subsubsection{Effect of Firm Size on Corporate Cash Holding}

Based on the results of testing the third hypothesis, it was found that firm size has a positive effect on the cash holding with a regression coefficient of 0,114202 . This positive influence shows that the larger the firm size, the greater the company holds cash (cash holding). The findings of this study are consistent with the research findings of [11], [8] and [1] which states that firm size has a significant positive effect on Cash Holding. Firm size influences the level of the company's cash holding because the company will try to maintain the level of its operations and investments [12]. Larger companies have the ability to maintain a large amount of cash holding, so that they can be used for reserves when there are unexpected events in the future.

\section{Conclusion}

This study aims to examine the effect of institutional ownership, profitability and firm size on the cash holding of the LQ45 Index Companies on the Indonesia Stock Exchange. The population of this study is the company of LQ 45 Index on the IDX for the period 2015-2017. The results of this study that instational ownership, competieiveness and firm size have a positive impact on corporate cas holding LQ45 index on the indonesia Stock Exchange, based on the findings of testing and study that were conducted.

\section{References}

[1] S. Ali, M. Ullah, and N. Ullah, "Determinants of Corporate Cash Holdings: 'A Case of Textile Sector in Pakistan,"” Int. J. Econ. Manag. Sci., vol. 5, no. 3, pp. 1-10, 2016.

[2] M. A. Ferreira and A. S. Vilela, "Why Do Firms Hold Cash? Evidence from EMU Countries," Eur. Financ. Manag., vol. 10, no. 2, pp. 295-319, 2004.

[3] T. R. Loncan and J. F. Caldeira, "Capital Structure, Cash Holdings and Firm Value : A Study of Brazilian Listed Firms," Rev. Contab. Finanças, vol. 25, no. 64, pp. 46-59, 2014.

[4] T. Opler, L. Pinkowitz, R. Stulz, and R. Williamson, "The Determinants and Implications of Corporate Cash Holdings," J. financ. econ., vol. 52, pp. 3-46, 1999.

[5] J. Kim, H. Kim, and D. Woods, "International Journal of Hospitality Management Determinants of corporate cash-holding levels : An empirical examination of the restaurant industry §,” Int. J. Hosp. Manag., vol. 30, no. 3, pp. 568-574, 2011. 
[6] A. Borici and A. Kruja, "Determinants of Firms's Cash Holding Evidence From Shkodra Region, Albania," Int. J. Econ. Commer. Manag., vol. IV, no. 4, pp. 41-52, 2016.

[7] A. Khan, M. Bibi, and S. Tanveer, "The Impact of Corporate Governance on Cash Holdings: A Comparative Study of The Manufacturing and Service Industry," Financ. Stud., vol. 20, no. 3, pp. 40-79, 2016.

[8] M. Shabbir, S. H. Hashmi, and G. M. Chaudhary, "Determinants of corporate cash holdings in Pakistan,” Int. J. Organ. Leadersh., vol. 5, no. January, pp. 50-62, 2016.

[9] A. M. Cheryta, Moeljadi, and N. K. Indrawati, "The Effect of Leverage , Profitability , Information Asymmetry, Firm Size on Cash Holding and Firm Value of Manufacturing Firms Listed at Indonesian Stock Exchange," Int. J. Res. Bus. Stud. Manag., vol. 4, no. 4, pp. 21-31, 2017.

[10] D. M. Sari and Ardian, "Cash Holding, Cash Flow dan Profitability: Studi pada Perusahaan Manufaktur yang Terdaftar di Bursa Efek Indonesia," J. Din. Akunt. dan Bisnis, vol. 6, no. 1, pp. 29-38, 2019.

[11] A. Kafayat, K. U. Rehman, and M. Farooq, "Factors Effecting Corporate Cash Holding of NonFinancial Firms in Pakistan," Acta Univ. Danubius. Economica, vol. 10, no. 3, pp. 35-41, 2014.

[12] M. D. S. Gomes, "The financial determinants of corporate cash holdings: Evidence from growing firms," 2012. 